\title{
Methylenetetrahydrofolate Reductase C677T Gene Polymorphism in Hepatitis C Virus-related Hepatocellular Carcinoma: An Egyptian Perspective Study
}

\author{
Wael Alkhiary ${ }^{\mathrm{a}}$ Tarek Shata $^{\mathrm{b}}$, Ola Ali El-Emam
}

\begin{abstract}
a Department of Clinical pathology, Faculty of Medicine, Mansoura University, Egypt. b Department of internal medicine, Gastroenterology and Hepatology unit Faculty of Medicine, Mansoura University, Egypt

Correspondence to: Ola Ali El-Emam, Department of Clinical pathology, Faculty of Medicine, Mansoura University, Egypt.
\end{abstract}

Email:

olaelemam@yahoo.com

Received: 4 August 2021

Accepted: 5 August 2021

\begin{abstract}
Hepatocellular carcinoma (HCC) is one of the most common cancers worldwide. It constitutes a major health problem in both developed and developing countries. In Egypt, the incidence of HCC is remarkably increasing because of the high prevalence of hepatitis $\mathrm{C}$ viral infection. In this study, we investigated whether methylenetetrahydrofolate reductase (MTHFR) C677T polymorphism has a role in the development of HCC in Egyptians. We recruited 128 patients diagnosed with HCC from the Hepatology and Gastroenterology Department, Mansoura Specialized Medical Center, MansouraUniversity Hospitals at the Delta region of Egypt. In addition, a total of 130participants who were confirmed as having hepatitis $\mathrm{C}$ viral infection constituted the other group in this study. The genotypes and allele distributions in both groups were investigated using PCR-RFLP and were compared. On comparing the frequency of alleles, genotypes in two patient groups revealed statistical significance for MTHFRC677T gene polymorphism in HCC patients. The $C T$ and $T T$ genotype and the $T$ allele of MTHFR C677T gene
\end{abstract} polymorphism all showed a significant risk of developing HCC [odds ratio (OR) $=1.92$; 95\% confidence interval $\quad(\mathrm{CI})=1.11-3.32 ; \quad P=0.019 ; \quad(\mathrm{OR}=4.91 ; \quad 95 \% \quad \mathrm{CI}=1.32-18.24 ; \quad P=0.018)$; (OR=2.113; 95\% CI=1.36-3.29; $P=0.001)$, respectively].

Keywords: hepatitis C, hepatocellular carcinoma, MTHFR polymorphism 


\section{Introduction}

Hepatocellular carcinoma (HCC), the main primary liver cancer, is considered as one of the most commonly occurring cancers worldwide. According to the statistics on cancer-related deaths, HCC represents the third main cause of cancer-related deaths in male population and the fourth main cause in female population, with nearly 600000 deaths per year worldwide [1]. The incidence rate of $\mathrm{HCC}$ varies widely as it ranges from 2.1 in Central America to 35.5 in Eastern Asia [2]. 'The burden of HCC has been increasing in Egypt, with a doubling in the incidence rate in the past 10 years' [3], mainly due to the high prevalence of hepatitis $\mathrm{C}$ virus (HCV) in Egypt [4,5]. The molecular pathogenesis of $\mathrm{HCC}$ is a complex genetic process with changes in the genomic landscape [6]. Nevertheless, there is no clinically available molecular marker for drug response, recurrence, and prognosis [7]. Methylenetetrahydrofolate reductase (MTHFR) is a critical enzyme in folate metabolism, converting 5,10- methyleneTHF, a carbon donor for nucleotide synthesis, to 5methyl THF. 5-Methyl THF is then essential for the remethylation process of homocysteine to methionine, which is subsequently used to generate the global methyl donor, SAM. MTHFR gene has been mapped to chromosome 1p36.3, with Between Februar a complex genomic structure [8]. The C677T polymorphism is a point mutation with the substitution of cysteine to thymine nucleotide at the position 677 on MTHFR gene, leading to the substitution of alanine to valine in the MTHFR enzyme, associated with hyperhomo- cysteinemia. This polymorphism is common in the general population, with a wide-range population specificity depending on the ethnic backgrounds $[9,10]$.

MTHFR C677T polymorphism seems to be involved in the genetic pathogenesis of many cancers [11]. However, studies on the associations of MTHFR genetic polymorphisms with HCC risk had inconsistent results [12-19]. Moreover, there are no available data in the Egyptian population. Therefore, we performed this study to assess whether MTHFR C677T gene polymorphism is associated with the risk for $\mathrm{HCC}$ in Egyptian patients.

\section{Patients and methods}

\section{Patients}

Between February 2012 and January 2015, 128 patients with $\mathrm{HCC}$ were recruited from 
the Hepatology and Gastroenterology Department, Mansoura Specialized Medical Center, Mansoura University Hospitals at the Delta region of Egypt. HCC was diagnosed using the laboratory data of $\alpha$-fetoprotein elevation, liver imaging (ultrasonography, computed tomography, MRI, and/or angiography), and/or histologic exam. Exclusion criteria for HCC patients were cardiac or renal diseases, overt diabetes, hepatitis B virus, and noncompliance. In addition, 130 unrelated participants with PCR-proven $\mathrm{HCV}$ were recruited from the outpatient clinic. Those participants who had no sign of HCC served as a disease control. An informed consent was obtained from all participants prior to their enrollment in the study, and approval of the local ethics committee of Mansoura University was also obtained.

\section{Genomic analysis}

From the whole venous blood samples, genomic DNA samples were extracted using GeneJET Whole blood Genomic DNA Purification Mini Kit (Thermo Scientific, Lithuania, US), according to the manufacturer's protocol and then were stored at $-20^{\circ} \mathrm{C}$. The MTHFR C677T polymorphism was genotyped in each case of both groups using PCR-RFLP method. Forward and reverse primers specified in Table 1 were used (Biosearch Technologies, USA). Amplification was performed in a Thermal Cycler (TC-312; Techne, Cambridge, UK): 5 min initially at $95^{\circ} \mathrm{C}, 40$ cycles of $30 \mathrm{~s}$ of denaturation at $95^{\circ} \mathrm{C}$, followed by $30 \mathrm{~s}$ of annealing at $60^{\circ} \mathrm{C}, 60 \mathrm{~s}$ of extension at $72^{\circ} \mathrm{C}$, and a final extension at $72^{\circ} \mathrm{C}$ for $7 \mathrm{~min}$. RFLP analysis was performed using the restriction enzyme FastDigest HinfI (Thermo Scientific FastDigest, USA). DNA fragments were resolved in 3\% agarose gel electrophoresis. An undigested 198 bp fragment showed the wild-type $\mathrm{CC}$ genotype, whereas the two digested fragments of 175 and $23 \mathrm{bp}$ represented the mutant TT genotype, and the three fragments of 198, 175, and $23 \mathrm{bp}$ denoted the heterozygous CT genotype.

\section{Statistical analysis}

The statistical analysis of data was performed using Excel (Microsoft Office 2013) and SPSS software (SPSS Inc., Chicago, Illinois, USA) version 20. Qualitative data were presented as frequency and percentage, whereas quantitative data were presented as mean and SD. Allele and genotype frequencies were obtained by direct counting. The $\chi 2$-test was utilized to calculate the genotypic and allelic differences in frequencies between patients and controls. 
The prevalence of genotypes was examined for deviation from the Hardy-Weinberg equilibrium using the exact $\chi 2$-test. The $\chi 2$ test and Fisher's exact test were used to compare groups. Odds ratio (OR) and 95\% confidence interval $(\mathrm{CI})$ were calculated. P value less than 0.05 was considered to be statistically significant (Bonferroni correction).

\section{Results}

The basic demographics and clinical characteristics of the two groups are summarized in Table 2. Both patients with $\mathrm{HCC}$ and $\mathrm{HCV}+$ were selected randomly from the population living in Delta in Egypt. All patient groups were of matched distributions for age, sex, and clinical risk factors.

Table 3 demonstrates the distribution of genotypes and alleles of the genotype and alleles of MTHFR C677T gene polymorphism among the $\mathrm{HCC}$ and $\mathrm{HCV}$ groups.

On comparing the frequency of alleles, genotypes in two patient groups revealed statistical significance for MTHFR C677T gene polymorphism in $\mathrm{HCC}$ patients. The CT and TT genotype and the T allele of MTHFR C677T gene polymorphism all showed significant risks for developing $\mathrm{HCC}$ $[(\mathrm{OR}=1.92 ; 95 \% \quad \mathrm{CI}=1.11-3.32 ; \quad \mathrm{P}=0.019)$; $(\mathrm{OR}=4.91 ; \quad 95 \% \quad \mathrm{CI}=1.32-18.24$; $\mathrm{P}=0.018) ; \quad(\mathrm{OR}=2.113 ; \quad 95 \% \quad \mathrm{CI}=1.36-$ 3.29; $\mathrm{P}=0.001)$, respectively].

Table 4 demonstrates the association between the clinical and laboratory variables and the MTHFR C677T polymorphisms in HCC patients. There were no statistically significant relation between the MTHFR C677T genotypes and any of the clinical or laboratory variables.

Table 1: Characteristics of used primers and restriction enzyme

\begin{tabular}{|c|c|c|c|c|c|c|}
\hline Polymorphisms & & Primers & $\begin{array}{l}\text { Annealing } \\
\text { temperature } \\
\left({ }^{\circ} \mathrm{C}\right) \\
\end{array}$ & $\begin{array}{l}\text { PCR } \\
\text { product } \\
\text { (bp) } \\
\end{array}$ & Digestion & $\begin{array}{l}\text { Bands } \\
\text { (bp) }\end{array}$ \\
\hline \multirow[t]{2}{*}{ MTHFR C677T } & Forward & $\begin{array}{l}\text { 5'-TGA AGGAGA ACG TGT } \\
\text { CTG CGG GA-3' }\end{array}$ & $60^{\circ} \mathrm{C}$ & 198 & Hinf I & 175,23 \\
\hline & Reverse & $\begin{array}{l}\text { 5'-AGG ACGGTG CGG TGA } \\
\text { GAG TG-3' }\end{array}$ & & & & \\
\hline
\end{tabular}

bp, base pair. 
Table 2 Demographic and clinical data of the studied groups

\begin{tabular}{|c|c|c|c|}
\hline \multirow[t]{2}{*}{ Parameters } & \multicolumn{2}{|c|}{ Groups } & \multirow[t]{2}{*}{$\mathbf{P}$} \\
\hline & $\operatorname{HCC}(n=128)[n(\%)]$ & $\operatorname{HCV}(n=130)[n(\%)]$ & \\
\hline \multicolumn{4}{|l|}{$\overline{\mathbf{S e x}}$} \\
\hline Male & $99(77.3)$ & $93(71.5)$ & 0.319 \\
\hline Female & $29(22.7)$ & $37(28.5)$ & \\
\hline Age (years) $($ mean \pm SD $)$ & $59.2 \pm 3.8$ & $58.3 \pm 4.6$ & 0.09 \\
\hline BMI $(\mathrm{kg} / \mathrm{m} 2)(\operatorname{mean} \pm \mathrm{SD})$ & $26.9 \pm 3.5$ & $27.5 \pm 3.1$ & 0.15 \\
\hline \multicolumn{4}{|l|}{ DM } \\
\hline Yes & $69(53.9)$ & $73(56.2)$ & 0.802 \\
\hline No & $59(46.1)$ & $57(43.8)$ & \\
\hline \multicolumn{4}{|l|}{ Cigarette smoking } \\
\hline Yes & $87(68)$ & $84(64.6)$ & 0.60 \\
\hline No & $41(32)$ & $46(35.4)$ & \\
\hline \multicolumn{4}{|l|}{ Bilharziasis } \\
\hline Yes & $58(45.3)$ & $51(39.2)$ & 0.46 \\
\hline No & $70(54.7)$ & $79(60.8)$ & \\
\hline Viral load (IU/ml) (median) & 680217 & 729461 & 0.181 \\
\hline \multicolumn{4}{|l|}{ Liver cirrhosis } \\
\hline Yes & $107(83.6)$ & $98(75.4)$ & 0.124 \\
\hline No & $21(16.4)$ & $32(24.6)$ & \\
\hline \multicolumn{4}{|l|}{ Child-Pugh grade } \\
\hline $\mathbf{A}$ & $72(56.3)$ & $67(51.5)$ & 0.457 \\
\hline B or $C$ & $56(43.7)$ & $63(48.5)$ & \\
\hline
\end{tabular}

DM, diabetes mellitus; HCC; hepatocellular carcinoma; HCV, hepatitis C virus.

Table 3: The genetic distribution of the genotypes and alleles of MTHFR C677T SNP in HCC cases compared with HCV cases

\begin{tabular}{|c|c|c|c|c|c|c|c|c|}
\hline Polymorphisms & \multicolumn{2}{|l|}{ Frequency } & \multicolumn{2}{|l|}{$\begin{array}{l}\mathrm{HCC} \\
(\mathrm{n}=128) \\
{[\mathrm{n}(\%)]}\end{array}$} & \multicolumn{2}{|l|}{$\begin{array}{l}\mathrm{HCV} \\
(\mathrm{n}=130) \\
{[\mathrm{n}(\%)]}\end{array}$} & OR $(95 \% \mathrm{CI})$ & $\mathrm{P}$ \\
\hline \multirow{5}{*}{$\begin{array}{l}\text { MTHFR } \\
\text { C677T }\end{array}$} & Genotypes & $\mathrm{CC}$ & $71(55.47)$ & & $95(73.08)$ & & $\mathrm{R}$ & - \\
\hline & & $\mathrm{CT}$ & $46(35.94)$ & & $32(24.62)$ & & $1.92(1.11-3.32)$ & $0.019 *$ \\
\hline & & TT & $11(8.59)$ & & $3(2.3)$ & & $4.91(1.32-18.24)$ & $0.018 *$ \\
\hline & Alleles & $\mathrm{C}$ & 188 & 73.44 & 222 & 85.38 & $\mathrm{R}$ & - \\
\hline & & $\mathrm{T}$ & 68 & 26.56 & 38 & 14.62 & $2.113(1.36-3.29)$ & $0.001 *$ \\
\hline
\end{tabular}

$\mathrm{R}=$ reference category $(\mathrm{OR}=1.0)$.CI, confidence interval; $\mathrm{HCC}$, hepatocellular carcinoma; HCV, hepatitis C virus; OR, odds ratio; SNP, single-nucleotide polymorphism. *Significant. 
Table 4: The associations between the clinical and laboratory variables and the MTHFR C677T polymorphisms in HCC patients

\begin{tabular}{|c|c|c|c|c|}
\hline Variables & $\begin{array}{l}\text { Genotypes } \\
C C[\mathrm{n}(\%)]\end{array}$ & $C T[\mathrm{n}(\%)]$ & $T T[\mathrm{n}(\%)]$ & $\mathbf{P}$ \\
\hline \multicolumn{5}{|c|}{$\overline{\text { Serum AFP }(\mathrm{ng} / \mathrm{ml})}$} \\
\hline$<400$ & $8(26.9)$ & $12(43.3)$ & $10(29.9)$ & 0.983 \\
\hline$\geq 400$ & $25(24.6)$ & $41(37.7)$ & $32(36.1)$ & \\
\hline \multicolumn{5}{|c|}{ Viral load (IU/ml) } \\
\hline$<400000$ & $14(34.7)$ & $19(38.8)$ & $13(26.5)$ & 0.915 \\
\hline$\geq 400000$ & $23(25.3)$ & $37(46.8$ & $22(27.9)$ & \\
\hline \multicolumn{5}{|c|}{ Tumor stage } \\
\hline I or II & $12(21.4)$ & $33(58.9)$ & $11(19.6)$ & 0.808 \\
\hline III or IV & $19(26.4)$ & $40(55.6)$ & $13(18.1)$ & \\
\hline \multicolumn{5}{|c|}{ Liver cirrhosis } \\
\hline Yes & $24(32.4)$ & $21(28.4)$ & $29(39.2)$ & 0.578 \\
\hline No & $13(24.1)$ & $18(33.3)$ & $23(42.6)$ & \\
\hline \multicolumn{5}{|c|}{ Child-Pugh grade } \\
\hline $\mathbf{A}$ & $28(33.3)$ & $34(40.5)$ & $22(26.2)$ & 0.854 \\
\hline B or $\mathbf{C}$ & $13(29.5)$ & $20(45.5)$ & $11(25.0)$ & \\
\hline
\end{tabular}

AFP, $\alpha$-fetoprotein; HCC, hepatocellular carcinoma.

\section{Discussion}

In the present study, $\mathrm{HCC}$ patients with $\mathrm{HCV}$ were found to have a higher proportion of $C T$ and $T T$ genotypes, compared with patients with $\mathrm{HCV}$ infection with no HCC. In the literature, contradictory results exist as regards the link between MTHFR C677T polymorphism and developing cancers, with some studies favoring its association with an increased risk for esophageal [20], gastric [21], ovarian [22], and lung cancers in Whites [23]. In contrast, MTHFR C677T single-nucleotide polymorphism (SNP) was linked to a reduced risk in colorectal carcinoma [24], lung cancer in Chinese population [25], and leukemia [26]. Although one meta-analysis denied an association between the MTHFR C677T polymorphism and risk for HCC [27], there are other reports suggesting the increased association of this SNP and HCC in Chinese [28-30], Korean [15], Indian [19], and Italian [28] populations and the overall increase in population susceptibility to HCC in other three meta-analyses [29-31]. Moreover, alcoholic cirrhotic men whose MTHFR C677T genotypes are TT were prone to a higher risk of developing HCC [16]. Our results are different from that observed in a previously published three studies, in European [32], Chinese [13], and Indian populations [19]. In the study in the European population, an association was 
established between MTHFR C677T polymorphism and the risk for $\mathrm{HCC}$ only in patients with end-stage liver disease due to alcoholism, but not in HCC patients with viral cirrhosis, as in our study. Moreover, although our results demonstrated about two-fold and five-fold increases in the risk of developing HCC in association with the $C T$ and $T T$ genotypes of MTHFR C677T polymorphism, respectively, Saffroy et al. [32] found that the wild MTHFR CC genotype was associated with the risk for $\mathrm{HCC}$, whereas the $T T$ genotype was related to a reduced risk for $\mathrm{HCC}$ (protective). Further, Mu et al. [13] found HCC to be more related to the $C T$ genotype; however, they did not report the etiology of the liver diseases. As regards the Indian population, both the $T T$ genotype and $\mathrm{T}$ allele were associated with about two- fold increase in the susceptibility to HCC. However, in contrast to our study, all HCC patients enrolled in that study were proved to be positive for hepatitis B virus but negative for $\mathrm{HCV}$ infection. Moreover, in the same study, the statistical analysis of the genotypic distribution was established between HBV-related HCC patients and healthy controls, but not with HBV-positive individuals with no HCC [19]. Importantly, the thrombo and genetic mechanisms of MTHFR 677TT were recently suggested to have a role in the pathogenesis of liver cirrhosis in patients without $\mathrm{HCV}$ and HBV infections [33].Given that MTHFRR enzyme is directly involved in folate metabolism and folate deficiency, it may be associated with cancer risk in two ways [34]. First, the low levels of 5,10methylenetetrahydrofolate $(M T H F)$ would increase the ratio of deoxyuridylate monophosphate to deoxythy- midylate monophosphate, leading to increased thymidine depletion and increased uracil incorporation into DNA instead of thymine, resulting in an increased susceptibility to point mutations with DNA/chromosome breakage and failure of DNA repair mechanisms. The DNA destabilization may lead to chromosome aberrations and thus malignant transformation $[35,36]$. Second, the alteration of the $S$ adenosyl-1-methionine (SAM) levels results in changes in methylation and modification of DNA conformation and the gene expression. A less active form of $M T H F R$ results in decreased SAM levels and, consequently, in hypomethylation [37], which predisposes to cancer. Thus, the MTHFR $T$ allele may either increase the risk for HCC from the theory of DNA methylation or decrease it according to the DNA synthesis point of view $[38,39]$. The above- mentioned data may explain the discrepancies between the different studies as regards the association of MTHFR C677T SNP with $\mathrm{HCC}$ risk. 
This study was limited by the absence of dietary folate measurement to determine any potential interaction between folate levels and MTHFR genotypes on risk for HCC. A second limitation may be the lack of the possible effect of other polymorphisms related to MTHFR gene and folate pathway on HCC. Third, because of high mortality rate in HCC patients in this single-center study, our sample may be not fully representative of the actual sample of HCC patients in our locality. However, this study has been strengthened by excluding the effect of $\mathrm{HCV}$ virus on the association of MTHFR C677T polymorphism with the risk for HCC, as we compared HCC patients with $\mathrm{HCV}$-positive individuals. According to our knowledge, this study is the first one to demonstrate that HCV-related HCC.

\section{References}

1 Singal AG, El-Serag HB. Hepatocellular carcinoma from epidemiology to prevention: translating knowledge into practice. Clin Gastroenterol Hepatol2015; 13:2140-2151.

2 Mittal S, El-Serag HB. Epidemiology of hepatocellular carcinoma: consider the population. J Clin Gastroenterol 2013; 47(Suppl):S2-S6.

3 Abdel-Atti E. HCC burden in Egypt. Gastroenterol Hepatol Open Access 2015; 2:00045.

4 Lehman EM, Wilson ML. Epidemiology of hepatitis viruses among hepatocellular carcinoma cases and healthy people in Egypt: a systematic review and meta-analysis. Int J Cancer 2009;
$124: 690-697$.

5 Baghdady I, EI-Kaffrawy N, Abd EI-Atti E, Abd EIBary N, Saber M. Study of the risk factors for hepatocellular carcinoma: effect of their synergism. J Am Sci 2013; 9:211-217.

6 Lee JS. The mutational landscape of hepatocellular carcinoma. Clin Mol Hepatol $2015 ; 21: 220-229$.

7 Kanda M, Sugimoto H, Kodera Y. Genetic and epigenetic aspects of initiation and progression of hepatocellular carcinoma. World J Gastroenterol 2015; 21:10584-10597.

8 Goyette P, Pai A, Milos R, Frosst P, Tran P, Chen Z, et al. Gene structure of human and mouse methylenetetrahydrofolate reductase (MTHFR). MammGenome 1998; 9:652-656.

9 Engbersen AM, Franken DG, Boers GH, Stevens EM, Trijbels FJ. Thermolabile 5,10methylenetetrahydrofolate reductase as a cause of mild hyperhomocysteinemia. Am J Hum Genet $1995 ; 56: 142-150$.

10 Liew SC, Gupta ED. Methylenetetrahydrofolate reductase (MTHFR) C677T polymorphism: epidemiology, metabolism and the associated diseases. Eur J Med Genet 2015; 58:1-10.

11 Izmirli M. A literature review of MTHFR (C677T and A1298C polymorphisms) and cancer risk. Mol Biol Rep 2013; 40:625-637.

12 Zhu ZZ, Cong WM, Liu SF, Xian ZH, Wu WQ. A study on the association of MTHFR c677T polymorphism with genetic susceptibility to hepatocellular carcinoma. Zhonghua Gan Zang Bing Za Zhi 2006; 14:196-198.

$13 \mathrm{Mu} \mathrm{LN}$, Cao W, Zhang ZF, Cai L, Jiang QW, You NC, et al. Methylenetetrahydrofolate reductase (MTHFR) C677T and A1298C polymorphisms and the risk of primary 
hepatocellular carcinoma (HCC) in a Chinese population. Cancer Causes Control 2007; 18:665-675.

14 Yuan JM, Lu SC, Van Den Berg D, Govindarajan S, Zhang ZQ, Mato JM, et al. Genetic polymorphisms in the methylenetetrahydrofolate reductase and thymidylate synthase genes and risk of hepatocellular carcinoma. Hepatology 2007; 46:749-758

15 Kwak SY, Kim UK, Cho HJ, Lee HK, Kim HJ, Kim NK, et al. Methylenetetrahydrofolate reductase (MTHFR) and methionine synthase reductase (MTRR) gene polymorphisms as risk factors for hepatocellular carcinoma in a Korean population. Anticancer Res 2008; 28:2807e11.

16 Fabris C, Toniutto P, Falleti E, Fontanini E, Cussigh xx, Bitetto D, et al. MTHFR C677T polymorphism and risk of $\mathrm{HCC}$ in patients with liver cirrhosis: role of male gender and alcohol consumption. Alcohol Clin Exp Res 2009; 33:102e7.

17 Liu J, Gao Y, Du Z, Yang B, Jing X, Wang Y. Relationship between the MTHFR C677T polymorphism and the outcome of hepatitis B virus infection. World Chin J Digestol 2010; 18:1555-1562.

18 Cui LH, Song Y, Si H, Shen F, Shin MH, Kim HN, et al. Folate metabolism- related gene polymorphisms and susceptibility to primary liver cancer in North China. Med Oncol 2012; 29:1837-1842.

19 Bharali D, Sarm MP, Kar P. Association of methylenetetrahydrofolate reductase (MTHFR) A1298C \& C667T gene polymorphism and hepatocellular carcinoma patients from India. Int $\mathbf{J}$ Biol Pharm Res 2015; 6:40-47.

20 Song C, Xing D, Tan W, Wei Q, Lin D.
Methylenetetrahydrofolate reductase polymorphisms increase risk of esophageal squamous cell carcinoma in a Chinese population. Cancer Res 2001; 61:3272-3275.

21 Shen H, Xu Y, Zheng Y, Qian Y, Yu R, Qin Y, et al. Polymorphisms of 5,10 methylenetetrahydrofolate reductase and risk of gastric cancer in a Chinese population: a case-control study. Int J Cancer 2001; 95:332336.

22 Gershoni-Baruch R, Dagan E, Israeli D, Kasinetz L, Kadouri E, Friedman E. Association of the C677T polymorphism in the MTHFR gene with breast and $\hat{a}$ or ovarian cancer risk in Jewish women. Eur J Cancer 2000; 36:2313-2316.

23 Siemianowicz K, Gminskiai J, Garczorz W, Slabiak N, Goss M, Machalski M, et al. Methylenetetrahydrofolate reductase gene C677T and A1298C polymorphisms in patients with small cell and nonsmall cell lung cancer. Oncol Rep 2003; 10:1341-1344.

24 Yin G, Kono S, Toyomura K, Hagiwara T, Nagano $\mathrm{J}, \quad$ Mizoue $\mathrm{T}$, et al. Methylenetetrahydrofolate reductase C677T and A1298C polymorphisms and colorectal cancer: the Fukuoka Colorectal Cancer Study. Cancer Sci 2004; 95:908-913.

25 Jeng YL, Wu MH, Huang HB, Lin WY, You SL, Chu TY, et al. The methylenetetrahydrofolate reductase $677 \mathrm{C}->\mathrm{T}$ polymorphism and lung cancer risk in a Chinese population. Anticancer Res 2003; 23:5149-5152.

26 Franco RF, Simoes BP, Tone LG, Gabellini SM, Zago MA, Falcao RP. The methylenetetrahydrofolate reductase C677T gene polymorphism decreases the risk of childhood acute lymphocytic leukaemia. Br J Haematol 
2001; 115:616-618.

27 Qin X, Peng Q, Chen Z, Deng Y, Huang S, Xu J, et al. The association between MTHFR gene polymorphisms and hepatocellular carcinoma risk: a meta-analysis. PLoS One 2013; 8:e56070.

28 D’Amico M, Pasta L, Sammarco P. MTHFR C677TT, PAI1 4G-4G, V Leiden Q506, and prothrombin G20210A in hepatocellular carcinoma with and without portal vein thrombosis. J Thromb Thrombolysis 2009; 28:70-73.

29 Qi X, Sun X, Xu J, Wang Z, Zhang J, Peng Z. Associations between methylenetetrahydrofolate reductase polymorphisms and hepatocellular carcinoma risk in Chinese population. Tumour Biol 2014; 35:1757e62

30 Qi YH, Yao LP, Cui GB, Liang J, Shao QJ, Yan LF, et al. Meta-analysis of MTHFR C677T and A1298C gene polymorphisms: association with the risk of hepatocellular carcinoma. Clin Res Hepatol Gastroenterol 2014;38:172e80.

31 Jin F, Qu LS, Shen XZ. Association between the methylenetetrahydrofolate reductase C677T polymorphism and hepatocellular carcinoma risk: a meta- analysis. Diagn Pathol 2009; 4:39.

32 Saffroy R, Pham P, Chiappini F, Gross-Goupil M, Castera L, Azoulay D, et al. The MTHFR $677 \mathrm{C}>\mathrm{T}$ polymorphism is associated with an increased risk of hepatocellular carcinoma in patients with alcoholic cirrhosis.Carcinogenesis 2004; 25:1443-1448.

33 D'Amico M, Pasta F, Pasta L. Thrombophilic genetic factors PAI-1 4G-4G and MTHFR 677TT as risk factors of alcohol, cryptogenic liver cirrhosis and portal vein thrombosis, in a Caucasian population. Gene 2015; 568:85-88.

34 Choi SW, Mason JB. Folate status: effects on pathways of colorectal carcinogenesis. J Nutr 2002; 132:2413Se8S.

35 Blount BC, Mack MM, Wehr CM, MacGregor JT, Hiatt RA, Wang G, et al.Folate deficiency causes uracil misincorporation into human DNA and chromosome breakage: implications for cancer and neuronal damage. Proc Natl Acad Sci USA 1997; 94:3290-3295.

36 McKinnon PJ, Caldecott KW. DNA strand break repair and human genetic disease. Ann Rev Genomics Hum Genet 2007; 8:37e55.

37 Stern LL, Mason JB, Selhub J, Choi SW. Genomic DNA hypomethylation, a characteristic of most cancers, is present in peripheral leukocytes of individuals who are homozygous for the C677T polymorphism in the methylenetetrahydrofolate reductase

gene. Cancer Epidemiol Biomarkers Prev 2000; 9:849-853.

38 Lin MR, Spitz MR, Wang Y, Schabath MB, Gorlov IP, Hernandez LM, et al. Polymorphisms of folate metabolic genes and susceptibility to bladder cancer: a case-control study. Carcinogenesis 2004; 25:1639-1647.

39 Sun H, Han MR, Zhai H, Cheng Xinhua, Ma K. Significant association between MTHFR C677T polymorphism and hepatocellular carcinoma risk: a meta-analysis. Tumour Biol 2014; 35:189e93.

To cite this article: Wael Alkhiary, Tarek Shata, Ola Ali El-Emam. Methylenetetrahydrofolate Reductase C677T Gene Polymorphism in Hepatitis C Virus-related Hepatocellular Carcinoma: An Egyptian Perspective Study. BMFJ 2021;38(2):784-793. DOI: 10.21608/bmfj.2021.89248.1452 